9. YouTube (2016). NAVAA. Conference "Kazymyr Malevych. Kyiv aspect", (Session 3), [online] Available at: <https://www.youtube.com/watch?v=ajRusGI1 Sqw> [Accessed 17.04.2018].

10. Koropenko, M. (2016). Fashion designer Fedor Vozianov: features of creative ways. Tradyciji Ta Novaciji u Vyshhyj Arkhitekturno-Khudozhnij Osviti [Traditions and Innovations in Higher Architectural-Artistic Education], no.4, pp. $40-45$.

11. Paintings by Kazymyr Malevych. Gallery, 1929-1931, [online] Available at: <http://kazimirmalevich.ru/1929_2/> [Accessed 17.04.2018].

12. Malevich K. (2013). Black square. Publishing group: «Lenizdat», «Komanda A».

13. Markade, Zh.-K. (2013). Malevych. Kyiv : Rodovid.

14. Channel 24. (2015). 24 'Ukrainian designers whose clothes are worn abroad', [online] Available at: <https://24tv.ua/ru/24_ukrainskih_dizajnera_odez hdu_kotoryh_nosjat_za_rubezhom_n602376 > [Accessed 17.04.2018].

(C) Михайлова Р. Д., 2018

(C) Коропенко М. В., 2018

УДК 7.032:391.5

\author{
Міненко Оксана Анатолї̈вна \\ кандидат мистеитвознавства, \\ Комунальний вищий навчальний заклад \\ «Хортицька національна навчально- \\ реабілітаційна академія», \\ Запоріжжя, Україна \\ oksana.ok986@gmail.com
}

\title{
АНТИЧНА ЗАЧІСКА В ІСТОРИКО-ХУДОЖНЬОМУ КОНТЕКСТІ ЕВОЛЮЦІї МОДИ
}

Метою статті $\epsilon$ визначення особливостей розвитку античної зачіски в історико-художньому контексті розвитку світової моди як важливого елементу вбрання та складової іміджу людини. У статті висвітлюються особливості змін традиційних рис античної зачіски в різних історичних періодах відповідно до вимог часу. Методи дослідження. Для досягнення мети було проаналізовано науково-теоретичну, мистецтвознавчу i методичну літературу. А також були використані методи наукового пізнання: проблемнохронологічний, конкретно-історичний, статистичний, описовий, логіко-аналітичний. Наукова новизна. Досліджується винайдення нових технологічних прийомів у формуванні зачісок та функціонуванні різних стилів, напрямків та смаків у сучасному перукарському мистецтві. Висновки. У процесі історичного розвитку традиційні риси античної зачіски як важливого елементу вбрання, складової іміджу людини, зазнали трансформації у відповідності зі 
зміною естетичних ідеалів конкретних історичних періодів - від античності до сучасності. Завдяки цьому класичні канони краси волосся, способи його укладання змінюються відповідно до вимог часу, збагачуючись та урізноманітнюючись.

Ключові слова: культура, Античність, зачіска, антична зачіска, мода, еволюція, краса, технологія

Миненко Оксана Анатольевна, кандидат искусствоведения, Коммунальное высшее учебное заведение «Хортицкая наџиональная учебнореабилитационная академия», Запорожье, Украина

Античная прическа в историко-художественном контексте эволюции моды

Целью статьи является определение особенностей развития античной прически в историко-художественном контексте развития мировой моды как важного элемента одежды и составляющей имиджа человека. В статье освещаются особенности изменений традиционных характеристик античной прически в различных исторических периодах в соответствии с требованиями времени. Методы исследования. Для достижения цели были проанализированы научно-теоретическая, искусствоведческая и методическая литературы. А также были использованы методы научного познания: проблемнохронологический, конкретно-исторический, статистический, описательный, логико-аналитический. Научная новизна. Исследуется изобретение новых технологических приемов в формировании причесок и функционировании различных стилей, направлений и вкусов в современном парикмахерском искусстве. Выводы. В процессе исторического развития традиционные черты античной прически как важного элемента одежды, составляющей имиджа человека, подверглись трансформации в соответствии с изменением эстетических идеалов конкретных исторических периодов - от античности до современности. Благодаря этому классические каноны красоты волос, способы их укладки изменяются в соответствии с требованиями времени, обогащаясь и видоизменяясь.

Ключевые слова: культура, Античность, прическа, античная прическа, мода, эволюция, красота, технология

Minenko Oksana, PhD in Art Criticism, Municipal Institution of Higher Education «Khortytsia National Educational Rehabilitation Academy», Zaporizhzhia, Ukraine fashion

Ancient hairstyle in the historical and artistic context of the evolution of

The purpose of the article is to determine the peculiarities of the development of ancient hairstyle in the historical and artistic context of the evolution of world fashion as an important element of clothing and part of the person's image. The article highlights the peculiarities of changes of traditional features of ancient hairstyles through different historical periods in accordance with the requirements of the time. The research methodology. To fulfill the research purpose, scientific- 
theoretical, art critical and methodical literature was analyzed. The following methods of scientific cognition were also used: problem-chronological, concretehistorical, statistical, descriptive, and logical-analytical.

The scientific novelty of the work lies in the research into the invention of new techniques in hairdressing and the functioning of different styles, trends and tastes in modern hairstyling. Conclusions. In the process of historical development, the traditional features of ancient hairstyle as an important element of clothing constituting the person's image have undergone transformation in accordance with the change of aesthetic ideals of specific historical periods - from antiquity to contemporaneity. Due to this fact, classic canons of beauty of hair and ways of its dressing have been changing in accordance with the requirements of the time, being constantly enriched and modified.

Key words: culture, Antiquity, hairstyle, ancient hairstyle, fashion, evolution, beauty, technology.

Вступ. Прагнення людини прикрасити, вдосконалити свою зовнішність простежується $з$ доби неоліту. Загалом ця риса $\epsilon$ біологічно обумовленою, адже в тваринному світі зовнішня привабливість завжди є запорукою успішного пошуку партнера $[10$, с. 56]. У людському суспільстві ця тенденція набула надзвичайно потужного розвитку й характерна для всіх періодів історії світової цивілізації. Еволюція суспільного ідеалу краси найповніше відбивається в творах образотворчого мистецтва - це найправдивіше свідчення, яке послідовно відтворює естетичні цінності, художній смак та уподобання різних соціальних груп населення, створюючи цілісний образ індивідуальної людини, який є відповідним особливостям історичної доби, передає думки й почуття пересічного члена суспільства. Створення цього образу відбувається різними засобами, проте передусім завдяки зовнішнім ознакам: одягові, макіяжу, прикрасам, зачісці. Остання в силу свого фізичного розташування - на голові, тобто у візуально найбільш виграшному місці - має чи не найважливіше значення.

Аналіз останніх досліджень і публікацій. Проблема розвитку і трансформації зачіски як феномена суспільно-естетичного порядку розглядалася низкою дослідників. Філософські та культурологічні аспекти зазначеної проблеми в поєднанні з модою на одяг розкривають у своїх працях дослідники сучасної доби - Л. Дихнич, Р. Захаржевська, Н. Камінська, А. Кікоть, Ю. Легенький, М. Мельник, С. Нікуленко, С. Пролєєв, Л. Ткаченко, О. Шевнюк, Ю. Шестопалова та ін. Різним аспектам взаємозв'язку функціонування старовинних елементів перукарського мистецтва в практиці сучасних модних віянь присвятили свої дослідження українські вчені - I. Борщ, Н. Вернигора, О. Костюк, Ю. Легенький, С. Лубянська, О. Одинець, Ю. Шестопалова та ін.

Зокрема, О. Одинець, реалізуючи теоретико-методологічну розвідку специфіки конструювання художнього образу, цікавиться значенням історичних стилів у процесі створення художніх образів людини сучасними майстрами-перукарями [10]. О. Костюк розглядає маску в обрядодіях ініціації в контексті перукарського мистецтва. На таких масках, зазвичай, зображуються чорні волосся, борода, вуса, занурені в глибинах орбіт очі й інші жахаючі риси 
вигляду чудовиська [3, с. 265]. У статті демонструються приклади ініціації з супроводженням виконання зачісок у контексті історичних типів певної культури [3]. С. Лубянська в навчальному посібнику дає приклади аналізу певного кольоротипу зовнішності за відповідним коліром волосся й звідси визначає взаємозв'язок макіяжу з певним типом зачіски й моделлю одягу [6]. У дисертаційному дослідженні І. Борщ обгрунтовується необхідність формування навичок комп'ютерного моделювання зачісок для забезпечення їх умілого підбору конкретною людиною з урахуванням особистих рис іiі зовнішності, характеру, стилю життя, професії, віку тощо. У роботі характеризуються умови ефективного формування комп'ютерних навичок моделювання модних зачісок і відповідного макіяжу [1].

Мета статті. Незважаючи на серйозні, експериментального характеру наукові праці, водночас залишається недостатньо висвітленою роль зачіски як одного із вагомих складових, iї пріоритетна функція в формуванні іміджу людини. Тому метою статті стає визначення особливостей розвитку античної зачіски в історико-художньому контексті еволюції моди.

Виклад основного матеріалу. Як випливає із самої назви, зачіска - це певний спосіб упорядкування на голові людини волосся через надання йому певної форми шляхом укладання, вкорочення, подовження, фарбування тощо, а також застосування для цього хімічної обробки або використання відповідних спеціальних предметів. Зачіска виникла як один 3 найдавніших здобутків духовної й тілесної людської культури. Через неї відчувається історична специфіка певної епохи, відтворюються етнічні риси конкретного індивіда, його соціальний статус у суспільстві, художні смаки та рівень загальної культури, стать та вік тощо.

Зачіски античної доби, зразки яких збереглися до нашого часу, свідчать про цілісність сприйняття давніми майстрами довершеної тілесної форми людини. Антропна естетика давньогрецької доби втілювалася в стереотипах зображення пофарбованих чоловічих (куросів) та жіночих (кор) статуй у відповідності 3 виробленими канонами. Довге завите волосся в античній грецькій скульптурі свідчить про досить розвинену моду і перукарську техніку. Ці статуї мають типізовані риси обличчя з легкою посмішкою, наділені прямим носом і напівкруглими бровами. Волосся мармурових дівчат античного періоду було золотавим, щоки фарбували в рожевий колір, очі - в синій. У результаті створювалося відчуття свята в поєднанні 3 простотою, зібраністю й конструктивністю форм та силуетів.

Цінну інформацію про довершену красу античної людини сучасні вчені зустрічають у творі давньоримського поета і філософа Публія Овідія Назона «Наука кохання». Його значущість полягає в тому, що, фіксуючи вже сталі на той час уявлення щодо фізичної краси, він водночас сформулював рекомендації для будь-кого 3 вільних громадян Риму, а не тільки аристократії того часу, тобто фактично документував у своїх творах тогочасні канони суспільної моди й естетики.

Вимоги до чоловічої краси подаються в творах Овідія у вигляді рекомендацій читачам: «...Намагайся бути охайним... Вистрижене волосся не 
повинне стояти щетиною, спотворюючи голову; волосся й борода мають бути підрізані умілою рукою. Нігтям бажано бути короткими та чистими, а з ніздрів не має виглядати волосся» [7, с. 60]. Чоловікам, за зауваженням Овідія, пасує недбала зачіска [7, с. 59], проте вони не мають бути скупими на компліменти щодо своєї «дами серця» («Не скупись розхвалювати зовнішність своєї красуні, iii волосся, тонкі пальці й маленьку ніжку» [7, с. 66]). Філософ розкриває античним аристократкам деякі косметичні секрети, які допомагають їм стати привабливими. Найкращого білого кольору шкіри він радив досягати за допомогою натирання крейдою, тоді як рожевих щік - втиранням рум'ян. Брови мають бути поєднані - цікава деталь краси того часу (очевидно, запозичена зі Сходу), штучні родинки - «мушки». Підводка очей широко використовувалася і в Єгипті, достатньо переглянути скульптурні зображення Нефертіті та ін. жіночих моделей, відображених у скульптурі чи малюнках). Для цього римські дами користувалися суриком, який в Римі добували 3 листя медуниці (воловика) [7, с. 204].

Й. Вінкельману, першому європейському вченому, що науково досліджував історію античного мистецтва й доводив пріоритет грецького мистецтва класики над римським, належить знаменита формула класичної краси, краси світу Фідія - «спокійна велич і шляхетна простота». Це краса аполлонічна, краса, яку сприймає і породжує душа елліна, яка любить і цінує понад усе міру, гармонію, правильну, регулярну форму, рівновагу частин, ясність і простоту, i шляхом мімесису переносить ці естетичні якості з об'єктивного світу космосу в об'єктивний світ мистецтва. Спокій, незворушність, раціональність, трохи холоду - такий дух відчув цей німецький теоретик неокласицизму XVIII ст. у статуях еллінських богів, героїв, атлетів після систематичного знайомства 3 археологічними скарбами Помпеїв.

3 вигляду античних статуй зрозуміло, що в створенні ідеального образу прекрасної людини, незалежно від статі, велика увага приділялася способу укладання волосся. Зазвичай, необрізане волосся укладалося у вигляді вузла або перев'язувалося стрічкою на потилиці. Різні види античних вузлів, надовго увійшовши в історію перукарської культури, й досі залишаються популярними в сучасних модниць. Перевірені часом античні прийоми перукарського мистецтва доводять свою актуальність і незамінність при вирішенні сучасних завдань створення певного образу.

«Вірогідно, - зазначає Й. Вінкельман, - що давньогрецькі митці встановили точні правила щодо різних пропорцій, й для кожного віку та стану були визначені певні розміри довжини, ширини й окружності. Вони були викладені в трактатах стародавніх митців, присвячених симетрії» [2, с. 11-12]. Художники й скульптори прагнули віднайти у співвідношенні частин окремих явищ природи й людського тіла ідеальні математичні закономірності та пропорції, і перенести їх на витвори мистецтва 3 метою вираження абсолютної краси природи. Одразу згадується поняття калокагатії, під яким стародавні греки розуміли гармонію тілесної та духовної досконалості, яка формується в процесі зміни поколінь у порівнянні з раптовим виявом краси, таланту, моральних чеснот. I незважаючи на те, що антична література не розтлумачила 
поняття класичного ідеалу, проте в ній існуюче поняття калокагатії за своєю суттю $є$ характеристикою класичного ідеалу. Таким чином, на думку О. Лосєва, саме в понятті калокагатії міститься концепт античного класичного ідеалу [5, c. 472-473].

Цікаво, що більше за жіночу в античній Греції цінувалася краса чоловіків. Наявність бездоганної зовнішності й досконалого тіла були важливими складовими грецького чоловічого іміджу. Вимоги до зовнішнього вигляду чоловіка в сучасній культурі - статечний вигляд, респектабельність, темні та неяскраві кольори, без косметики й прикрас - суперечать давньогрецьким смакам і уявленням. Так, син богів Зевса й Лето Аполлон (грец. Apollon осяйний) вважався уособленням довершеної чоловічої краси. Грецькими скульпторами він зображувався вродливим, високим та струнким юнаком 3 довгим золотавим волоссям, який тримає в руках стрілу або ліру, інколи біля його ніг лежить вовк. В елліністичну епоху Аполлона зображували оголеним юнаком з кітарою. Статуї цього давньогрецького божества, виконані Скопасом, Леохаром та Праксителем, збереглися до сьогодні в копіях римських митців.

Водночас жінки високо шанувалися, зокрема, в мікенській культурі. Символічний образ цієї культури - так звана «Парижанка» - фрагмент розпису, знайдений у Кноссі. Перед нами майже сучасна, дуже «нафарбована» модниця з високою зачіскою з завитого розпущеного волосся, одягнена в модну жилетку 3 глибоким декольте. Ця історично-регіональна мода зазнала бурхливого розквіту жіночої краси в ії̈ первозданно чистій пластиці [5].

Жіночі зачіски прикрашалися різними шпильками та гребенями. Вироблені 3 золота й срібла, 3 фігурками звірів та людей, різними скульптурними групами на кінцях, такі шпильки були справжніми зразками творів мистецтва. Гребені вирізали 3 кістки, цінних порід дерев з використанням інкрустації дорогоцінним камінням: сапфірами, рубінами, сердоліками. Майстерне різьблення та карбування було звичним у виготовленні прикрас для зачісок.

Середньовічна культура 3 iï культом мучеництва, запозиченим від християнства, підносила сферу сакрального, дедалі розпредметнюючи тіло моди й будуючи його нематеріальним та ірреальним. Водночас можна помітити, що в Середньовіччі зображення людей рефлектують певні поширені античні риси. Обриси тіла, і чоловічого, і жіночого, не підкреслюються. Одяг, у цілому подібний давньогрецьким тунікам та хітонам, вільно спадає, приховуючи реальні форми - свідчення відсутності самоцінного значення фізичної досконалості. Дискурс людського тіла поступово змінився дискурсом поверхні, що інтерпретувалася як багатошаровий комплекс соціально-космічної інформації.

У жіночих зображеннях голову прикриває накидка, іноді на голову накинутий плащ, який у даному випадку виконує функцію капюшона, волосся зібране. У X-XII ст. був розповсюджений звичай носити одяг, що облягав форми тіла, стає модним ходити з довгим розпущеним волоссям або заплітати коси, ефектно перевиті стрічками $з$ парчі, носити віночки. Жінки відрощували довге волосся й носили його розділеним на два пасми, заплетені в коси. 
3 XIII ст. практикувалися дівочі зачіски, що хвилею спадали на плечі. Заміжні жінки приховували зібране волосся під хусткою або капелюхом.

Середньовічна чоловіча зачіска нагадувала щось схоже між римською модою й старовинним німецьким звичаєм, за яким довге волосся вважалося ознакою знатності. До середини XII ст. чоловіки ретельно голили підборіддя й щоки, часом відрощуючи вуса; волосся ж підстригали коротко. Потім повернулися до варіанту довгого волосся й відпускали бороди, відповідно довгополому вбранню. Проте ця зачіска протрималася недовго: впровадження важкого горщикоподібного шолома спонукало лицарську верству відмовитися від носіння бороди. Вкорочення та спрощення одягу стало адекватним короткій зачісці з вистриженим чубчиком.

Хоча в культурі Ренесансу з повагою ставилися до спадку античної епохи, проте вплив його, на думку провідних вчених, не був особливою рисою культури зазначеного історичного періоду. Якщо антична калокагатія виступала гармонізаційним принципом тілесного й духовного, естетичного та етичного, то естетика Відродження, будучи ціннісною складовою скерованого індивідуалістичного світогляду, віддає перевагу тілесному. Тому ренесансний ідеал можна вважати псевдоморфозом античності (за термінологією О. Шпенглера).

Ренесансна жінка на полотнах художників Доменіко Гірландайо (14491494), Якопо Тінторетто (1518-1594) й Тиціана Вечелліо (1489/90? - 1576) вражає красою розкішного волосся. Золотисте, пишне, обвите низками перлин, воно чарує i привертає до себе увагу глядачів. Дивовижно привабливими є, наприклад, жіночі героїні робіт Тиціана: «Венера перед дзеркалом», «Любов земна й любов небесна», «Діана і Каллісто» та ін. Саме золотаве волосся спостерігаємо на портреті Джіневри де Бенчі (1474 р.) пензля Леонардо да Вінчі. Це не означає, що інший колір не зустрічається: джорджонівська «Спляча Венера», як і його ж «Юдіфь», мають чорне волосся. Але перевагу надавали саме золотавим, рудим, червонястим відтінкам завдяки їх ефектності.

Нерідко стрижнем зачіски італійської жінки доби Ренесансу виступали добірно укладені коси або ж кучері, практикувалися подібні до філіграні «сіткичіпці» або ж мініатюрні, перевиті стрічками, овальні шапочки (berretta), які носили на потилиці. Вельми модною вважали гірлянду - широкий вінок зі сплетених квітів. Модним протягом тієї історичної доби вважали високе відкрите чоло, спеціально збільшене - для цього видаляли частину волосся над лобом та вищипували брови. Такі жіночі образи можна побачити на картинах німецького майстра Лукаса Кранаха Старшого та голландця Яна ван Ейка.

Волосся жінки XVI ст. - у відповідності 3 баченням монаха валламброзького ордена Аньоло Фиренцуоли у трактаті «Про красу жінок», мало бути ніжним, пишним, довгим і хвилястим, уподібнюючись кольором золоту або меду, немов гаряче сонячне проміння [5, с. 111-112]. У моді були зачіски античних зразків - високі, хвилясті, пишні, прикрашені стрічками 3 коштовних тканин й квітами. Завдяки технологічній майстерності перукарів у зачісках використовувалися різних видів завивки волосся, у результаті модниці отримували прекрасні кучері - круглі, стрічкові, трубчасті, спіральні 
та ін. або їх поєднання в конкретній зачісці. Антична жінка дозволяла собі прикрасити зачіску «пучком» свого власного волосся або майстерно зробленим шиньйоном, який закріплювала гребінцем, шпильками або сіткою. Не забувала й про чубчик на чолі. Для краси на голові носили діадеми й золоті та срібні обручі, ще й прикрашені пером. Прикрашали себе жінки також фероньєрками красивим коштовним каменем на чолі, закріпленим шнуром у зачісці.

Що ж до чоловічих зачісок, то Високе Відродження в контексті моди орієнтувало на шляхетне чоловіче обличчя, окресленого широкою бородою й вишуканими бакенбардами. Чоловіча зачіска спрямовувалась у напрямку спокійних обрисів. Борода мала акцентувати увагу на суворому виразі обличчя. Будь-які вимоги щодо довжини волосся варіювали в різних країнах, однак загалом типова чоловіча зачіска була короткою, іiі форма часто залежала від соціального стану, професії тощо. 3 плином часу першість у галузі жіночої перукарської моди залишалася за Францією, чоловічої - за Англією.

Добу бароко заслужено називають добою перук. Однак варто зауважити, що перуки використовувалися ще в Давньому Сгипті, в країнах Близького Сходу, у Давній Греції та Римі. Носили їх здебільшого на виголеній голові для захисту від сонця. У косметичних цілях перуки приклеювали до існуючого волосся воском тощо. Із занепадом Західної Римської імперії перуки в Свропі перестали носити і їх використання відновилося вже у XVI ст., передусім у косметичних цілях. Завдяки французьким королям Луї XIII і особливо XVI, які передчасно почали лисіти і бажали приховати цей недолік, перуки знову стали шалено популярними як серед чоловіків, так і серед жінок - власне, жінки носили не перуки, а куафюри - невеликі головні убори 3 волосся для надання обсягу для власного волосся [7, с. 380]. Чоловічі перуки робили 3 косичками й підпудрювали сумішшю 3 тонкоподрібненого крохмалю і натуральних ароматизаторів у вигляді помаранчевого цвіту або лаванди [11].

Перуки носили солдати й офіцери європейських армій. Утім, після того як британський уряд запровадив досить високий податок на пудру для перук, іiі використання почало стрімко занепадати, а разом 3 цим і поширення перук поступово зійшло майже нанівець.

Хоча й досі перуки традиційно одягають працівники судової системи низки країн Британської Співдружності під час судових засідань, а також члени деяких військових формувань під час урочистих церемоній. У наш час перуки в повсякденному житті використовують прибічники деяких ортодоксальних релігій, деякі зірки поп-культури (Дайяна Росс, Тіна Тернер, Леді Гага), пацієнти після променевої терапії та ін.

У XIX-XX ст. набули поширення так звані постиші (з франц. Postiche перекл. як штучний, накладний) - жіночі штучні кучері, що прикріплювалися до власного волосся. Оскільки довжина жіночого волосся в добу емансипації почала стрімко зменшуватися, ці невеликі пристосування давали можливість урізноманітнити зачіску. 3 середини XX ст. такі аксесуари (а також цілі перуки) почали робити з акрилового волокна, що знизило їх собівартість.

Естетика доби модерну розробляла тип «природної людини», активної, гнучкої, емоційної. Найвідомішим для того часу модним перукарем, який 
успадковував імпульси культуротворчості, реагуючи на античні та на східні вПливи, був Поль Пуаре. П. Пуаре звільнив жінок від шкідливих для здоров’я тугих корсетних пристосувань і маніпуляцій з пишними зачісками. Він бажав, щоб жінки відчували та любили своє тіло.

Початок XX ст. знівелював жіноче волосся як елемент людської краси. Коротке волосся й маленькі капелюшки, які щільно облягають голову, відтінюють красу шиї, на яку майже не звертали увагу з часів Нефертіті. Ретельно окреслюється морфологія обличчя: ліплення черепа та вилиць. Жіноча врода інтерпретується тяжінням до унісексу.

Ретушування краси жіночого волосся не вплинуло на ацент очей, як у добу Середньовіччя, коли приховувалися принади оголеного жіночого волосся. Жіноча зачіска подається короткою й позбавленою колишньої пишності. Стиль жіночої зачіски середини ХХ ст. характеризується чіткими пропорціями, природними лініями. Волосся розділено прямим проділом, причесане щіткою й звисає кучерами з двох сторін обличчя.

Мода на зачіски в 1990-ті рр. поєднала класику та сучасність. Завдяки використанню як класичних технологій, так i новітніх, впроваджується об’єднання чоловічих та жіночих прийомів для обробки волосся. У результаті модниці та модники мають легкі, колоритні зачіски, які виглядають і романтично, і стильно [10, с. 171].

У даний час у контексті історії зачіски варто визначити як еклектичний і демократичний. У нашу добу використовують найрізноманітніші стилі зачісок. Набули неабиякої популярності етномотиви на зразок дрібних африканських косичок (дредів) або однієї суцільної коси, що обрамляє голову. Тобто, започаткована в добу античності антропоморфна інтерпретація зачіски набула в наш час урізноманітнення. У цьому контексті правомірно кваліфікувати наявність найрізноманітніших форм 3 прямими, кривими та ламаними лініями, закінченою або незавершеною композицією тощо.

Наукова новизна. Досліджується винайдення нових технологічних прийомів у формуванні зачісок та функціонуванні різних стилів, напрямків та смаків у сучасному перукарському мистецтві.

Висновки. Отже, протягом історичного розвитку традиційні риси античної зачіски як важливого елементу вбрання, складової іміджу людини, зазнали трансформації у відповідності зі зміною естетичних ідеалів конкретних історичних періодів - від античності до сучасності. Завдяки цьому класичні канони краси волосся, способи його укладання змінюються відповідно до вимог часу, збагачуючись та урізноманітнюючись. У зв'язку з відкриттям нових технологічних прийомів в обробленні волосся та конструюванні зачісок, у поєднанні 3 повною свободою стилів, напрямків та смаків основою оформлення зачісок $\epsilon$ різні їх форми 3 різною довжиною волосся та різноваріантним колоруванням. Перукарська мода на сучасному пї розвитку орієнтується на досягнення блиску та оновлення структури здорового волосся. 


\section{Список використаних джерел}

1. Борщ I. П. Формування умінь комп'ютерного моделювання у майбутніх фахівців-дизайнерів зачіски та макіяжу: дис. на здобуття наук. ступ. канд. пед. наук: спец.: 13.00.04 «Теорія і методика професійної освіти» / I. П. Борщ ; Київський університет імені Бориса Грінченка, 2012. - 297с.

2. Винкельман И. И. История искусства древности. Малые сочинения / И. И. Винкельман. - Ленинград : ОГИЗ,1933. - 432 с.

3. Костюк О. П. Маска в обрядах инициации и ее актуализация в модерном обществе / О. П. Костюк // Ученые записки Таврического национального университета им. В. И. Вернадского. Серия: Философия. Культурология. Политология. Социология. - 2014. - Т. 27(66). - № 1/2. C. $263-270$.

4. Легенький Ю. Г. Система моды: культурология, этетика, дизайн / Ю. Г. Легенький, Л. П.Ткаченко. - Киев : ГАЛПУ, 1998. - 224 с.

5. Лосев А. История античной эстетики. Последние века. Кн. 1. / А. Лосев. - Москва : Искусство, 1988. - 414 с.

6. Лубянська С. П. Кольоровий тип зовнішності i iндивідуальне моделювання зачіски / С. П. Лубянська. - Київ : КАПМ, 2016. - 27 с.

7. Овидий. Наука любить / Овидий. - Москва : Вернисаж, 1992. - 220 с.

8. Словник української мови. В 11 т. Т. 4. / АН УРСР, Ін-т мовознавства; за ред. І. К. Білодіда. - Київ : Наукова думка, 1970-1980. - С. 380.

9. Фрейд 3. Очерки по психологии сексуальности / 3. Фрейд. - Москва : Наука-ПРЕСС, 1989. - 84 с.

10. Odynets H. A. The role of historical styles to create artistic and functional image professionals in hairdressing and makeup / H. A. Odynets // Science and Education a New Dimension. Pedagogy and Psychology. - 2013. - 1(7). - issue 14. pp. 169-173.

11. The Art and Craft of Hairdressing / Gilbert A. \& N. E. B. Wolters (eds). The New Era Publishing Company, Ltd. London, 1964. - 661 p.

\section{References}

1. Bilodida, I. ed. (1970-1980). Ukrainian language dictionary. In 11 vols. Vol. 4. Kyiv: Naukova dumka.

2. Borshch, I. (2012). Formation of computer modeling skills in future hair stylists and makeup artists. D.Ed. Borys Grinchenko Kyiv University.

3. Vinkelman, I. (1933). The history of ancient art. Short essays. Leningrad: Gosudarstvennoe izdatelstvo izobrazitelnykh iskusstv.

4. Kostiuk, O. (2014). Mask in initiation ceremonies and its actualization in modern society. Uchenye zapiski Tavricheskogo natsional'nogo universiteta im. V. I. Vernadskogo. Seriya: Filosofiya. Kul'turologiya. Politologiya. Sotsiologiya [Scientific notes of Tavrida National Vernadsky University. Series: Philosophy. Culturology. Political science. Sociology], vol. 27(66), no. 1/2, pp. 263-270.

5. Lehenkyi, Yu. (1998). Fashion system: culturology, aesthetics, design. Kyiv: State Academy of Light Industry of Ukraine. 
6. Losev, A. (1988). The history of ancient aesthetics. The past centuries. Book 1. Moscow: Iskusstvo.

7. Lubianska, S. (2016). The color type of appearance and individual hairstyle design. Kyiv: KAMP.

8. Publius Ovidius Naso. (1992). The science of love. Moscow: Vernisazh.

9. Freud, S. (1989). Essays on the psychology of sexuality. Moscow: NaukaPRESS.

10. Odynets, H. (2013). The role of historical styles to create artistic and functional image professionals in hairdressing and makeup. Science and Education a New Dimension. Pedagogy and Psychology. 1(7), issue 14. pp. 169-173.

11. The Art and Craft of Hairdressing / ed. N.E.B. Wolters // The New Era Publishing Company, Ltd. London, 1963. - 661 p.

(с) Міненко О. А., 2018

УДК 792.024.3:391

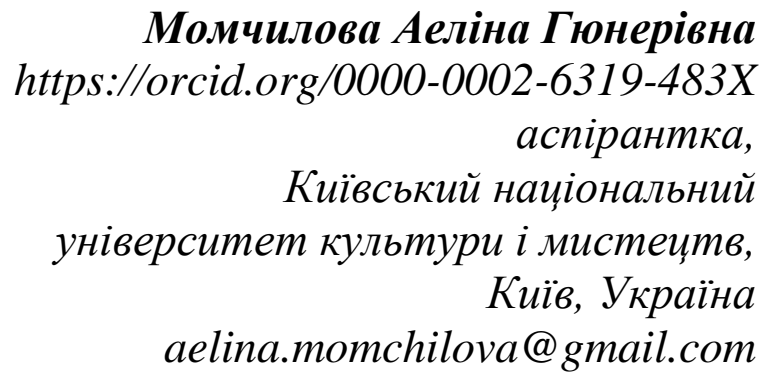

\section{НАУКОВО-ТЕОРЕТИЧНІ ЗАСАДИ ДОСЛІДЖЕННЯ ГРИМУ В МИСТЕЦЬКИХ ПРАКТИКАХ}

Мета роботи - прослідкувати трансформацію змістовного наповнення слова «грим» у різних літературних джерелах та мистецьких практиках. Розглянути наукову літературу з дослідження гриму в різних галузях знань й виявити не розкриті питання, що впливають на формування культури гриму в XXI ст. Методи дослідження. Основою даного дослідження є джерела, в яких було проаналізовано процес формування поняття «грим». Відповідно до цього проведено аналіз змін поняттям «грим» у контексті соціально-культурних процесів, виявлено та висвітлено джерельну базу та науково-методологічні підходи до розв'язання проблеми. Наукова новизна. У дослідженні було виявлено, що різні періоди розвитку поняття «грим» мали свої характеристики та сфери використання. У статті вперше поняття «грим» розглядається в контексті вимог модних інновацій XXI ст. Подано аналіз наукової літератури, в якій подається мистецтвознавчий аналіз зазначеної проблеми в контексті принципів та технік оздоблення тіла людини в різних видах мистецтв. Висновки. Проаналізувавши численні праці науковців у сфері мистецтва, філософії, Fashion-індустрії, ми виявили, що значна кількість робіт демонструє 